\title{
EFEKTIVITAS BAHAN AJAR BERBASIS PENEMUAN TERBIMBING UNTUK MENINGKATKAN KEMAMPUAN KOMUNIKASI MATEMATIS PESERTA DIDIK KELAS VIII SMP
}

\author{
Wiga Ariani \\ Universitas Krisnadwipayana, Jl kampus UNKRIS Jatiwaringin P.O Box 7774/Jat CM Jakarta 13077 \\ wigaariani@unkris.ac.id
}

\begin{abstract}
The aim of this research was to determine the effectiveness of guided inquiry based instructional materials in improving students' mathematical communication ability. The subject of the research was 34 the students in class $\mathrm{VIII}_{7}$ of SMPN 12 Padang. The effectiveness was viewed from the students' mathematics communication ability after learning by using guided inquiry based instructional materials. The communication skills of students are obtained from tests given in the form of essay tests with 6 items in the Pythagoras theorem lesson. I scoring rubrics indicators of mathematical communication ability were developed by referring to NCTM (1989) and Sumarmo (2003). The scoring results will be compared with the Minimum Completion Criteria (KKM) set by the school with a value of 75 . There were 34 students taking essay tests. The value of students $\geq 75$ as many as 24 people with a percentage of $70.5 \%$, while the value of 10 other people $<75$ with a percentage of $29.5 \%$. More than $65 \%$ of students are above KKM. so that guided inquiry based instructional materials can improve students' mathematical communication ability.
\end{abstract}

Keywords: effectiveness, instructional material, guided inquiry, and the mathematical communication ability

\begin{abstract}
Abstrak
Penelitian ini bertujuan untuk mengetahui efektivitas bahan ajar berbasis penemuan terbimbng dalam meningkatan kemampuan komunikasi matematis peserta didik. Subjek penelitian adalah peserta didik kelas VIII 7 SMPN 12 Padang sebanyak 34 orang. Keefektifan bahan ajar di lihat dari kemampuan komunikasi matematis peserta didik setelah pembelajaran dengan menggunakan bahan ajar berbasis penemuan terbimbing. Kemampuan komunikasi peserta didik diperoleh dari tes yang diberikan dalam bentuk tes esai sebanyak 6 butir soal pada materi teorema Pythagoras. Rubrik penskoran indikator kemampuan komunikasi matematis, dikembangkan dengan merujuk pada NCTM (1989) dan sumarmo (2003). Hasil penskoran akan dibandingkan dengan Kriteria Ketuntasan Minimal (KKM) yang ditetapkan oleh sekolah yaitu nilai 75. Peserta didik yang mengikuti tes essai sebanyak 34 orang. Nilai peserta didik $\geq 75$ sebanyak 24 orang dengan persentase 70,5\% sedangkan nilai 10 orang lainnya $<75$ dengan persentase $29,5 \%$. Lebih dari $65 \%$ peserta didik diatas KKM sehingga bahan ajar berbasis penemuan terbimbing dapat meningkatkan kemampuan komunikasi matematis peserta didik.
\end{abstract}

Kata kunci: efektivitas, bahan Ajar, penemuan terbimbing, dan kemampuan komunikasi matematis

\section{PENDAHULUAN}

Saat ini masih banyak peserta didik yang tidak mampu menyelesaikan soal matematika yang berbentuk narasi, hal ini disebabkan karena kemampuan komunikasi peserta didik masih rendah, padahal komunikasi matematis memliki peran penting bagi peserta didik karena membantu mereka dalam memecahkan masalah matematis yang tingkat nya lebih rumit.

Salah satu solusi yang dapat membantu meningkatkan komunikasi matematika peserta didik adalah dengan menerapkan model pembelajaran penemuan terbimbing. Menurut permendiknas nomor 58 (2014: 359), "penemuan terbimbing adalah proses belajar yang didalamnya tidak disajian suatu konsep dalam bentuk jadi (final), tetapi peserta didik dituntut untuk mengorganisasikan sendiri cara belajarnya dalam menemukan konsep”. penemuan terbimbing mengajak peserta didik untuk ikut belajar menemukan kosep sehigga berdampak pada peningkatan komunikasi matematis. 
Penerapan model pembelajaran ini disertai dengan bahan ajarnya. Tujuannya agar dalam pembelajaran tidak terjadi kesenjangan antara model dengan bahan ajar yang digunakan. Berdasarkan masalah tersebut maka dikembangkan bahan ajar berbasis penemuan terbimbing untuk meningkatkan kemampuan matematis peserta didik. Bahan ajar yang dikembangkan berbentuk Lembar Kerja Pesersa Didik (LKPD). Dalam penelitian ini keefektifan bahan ajar yang dikembangkan sangat penting terhadap kemampuan komunikasi matematis peserta didik.

Menurut Kamus Besar Bahasa Indonesia (KBBI) (2002: 219) efektivitas, artinya ada dampak, pengaruh, dan hasil yang ditimbulkan. Berkaitan dengan keefektifan dalam penelitian pengembangan, Akker (1999: 10) menyatakan : "Effectiveness refer to the extent that the experiences and outcomes with theintervention are consistent with the intended aims." Artinya, keefektifan mengacu pada tingkatan bahwa pengalaman dan hasil intervensi konsisten dengan tujuan yang dimaksud. Menurut Akker (1999) dalam Yazid ada dua aspek keefektifan yang harus dipenuhi oleh suatu bahan ajar, yaitu: 1) ahli dan praktisi berdasarkan pengalamannya menyatakan bahwa bahan ajar tersebut efektif dan 2) secara operasinal bahan ajar tersebut memberikan hasil sesuai yang diharapkan. Bahan ajar berbasis penemuan terbimbing dikatakan efektif apabila memberikan dampak yang baik bagi penggunanya dilihat dari hasil kemampuan komunikasi matematis peserta didik.

\section{METODE}

Jenis penelitian yang dilakukan adalah penelitian pengembangan dengan model pengembangan yang diadaptasi dari model Tjeer Plomp. Subjek penelitian ini adalah peserta didik kelas VIII 7 SMPN 12 Padang.

Instrument pengumpulan data untuk melihat keefektifan bahan ajar adalah soal tes kemampuan komunikasi matematis dengan bentuk tes essai. Tes esai bertujuan untuk melihat seberapa jauh peserta didik mampu menggunakan pengetahuan yang telah mereka bangun untuk menyelesaikan permasalahan matematika. soal tes disusun berdasarkan materi yang dipelajari yaitu teorema Pythagoras sebanyak 6 butir. Untuk mendapatkan soal tes yang baik dilakukan langkah-langkah sebagai berikut:
a. Membuat kisi-kisi tes berdasarkan indikator pelajaran yang akan dicapai
b. Menyusun tes sesuai dengan kisi-kisi
c. Memvalidasi tes

Validasi tes yang digunakan adalah validasi ahli. Soal yang diberikan pada kelas sampel telah divalidasi oleh 2 orang dosen pendidikan matematika dan 1 orang guru matematika SMP. Setelah disetujui oleh validator maka soal tes kemampuan komunikasi matematis dapat digunakan.

Mengukur kemampuan komunikasi matematis peserta didik menggunakan rubrik penskoran kemampuan komunikasi matematis. Indikator rubrik rubrik peskoran kemampuan komunikasi matematis yang dikembangkan merujuk pada NCTM (1989) dan sumarmo (2003). 


\section{Tabel 1.}

Rubrik Analitik Skala 4 Kemampuan Komunikasi Matematis

\begin{tabular}{|c|c|c|c|c|}
\hline $\begin{array}{l}\text { Skala } \\
\text { Indikator }\end{array}$ & 1 & 2 & 3 & 4 \\
\hline $\begin{array}{l}\text { Menjelaskan situasi } \\
\text { dan relasi matematika } \\
\text { secara lisan atau tulisan } \\
\text { dengan benda nyata, } \\
\text { gambar, grafik dan } \\
\text { aljabar }\end{array}$ & $\begin{array}{l}\text { menjelaskan } \\
\text { situasi dan relasi } \\
\text { matematika } \\
\text { secara lisan atau } \\
\text { tulisan dengan } \\
\text { benda nyata, } \\
\text { gambar, grafik } \\
\text { dan aljabar belum } \\
\text { benar }\end{array}$ & $\begin{array}{l}\text { menjelaskan } \\
\text { situasi, dan } \\
\text { relasi } \\
\text { matematika } \\
\text { secara lisan atau } \\
\text { tulisan dengan } \\
\text { benda nyata, } \\
\text { gambar grafik } \\
\text { dan aljabar } \\
\text { dengan sebagian } \\
\text { benar }\end{array}$ & $\begin{array}{l}\text { menjelaskan } \\
\text { situasi, dan } \\
\text { relasi } \\
\text { matematika } \\
\text { secara lisan atau } \\
\text { tulisan dengan } \\
\text { benda nyata, } \\
\text { gambar, grafik } \\
\text { dan aljabar } \\
\text { dengan sebagian } \\
\text { besar benar }\end{array}$ & $\begin{array}{l}\text { menjelaskan ide, } \\
\text { situasi, dan } \\
\text { relasi } \\
\text { matematika, } \\
\text { secara lisan } \\
\text { maupun tulisan, } \\
\text { dengan benda } \\
\text { nyata, gambar, } \\
\text { grafik dan } \\
\text { aljabar dengan } \\
\text { benar }\end{array}$ \\
\hline $\begin{array}{lr}\text { Menyatakan } & \text { peristiwa } \\
\text { sehari-hari } & \text { dalam } \\
\text { bahasa atau } & \text { simbol } \\
\text { matematika } & \end{array}$ & $\begin{array}{l}\text { menyatakan } \\
\text { peristiwa sehari- } \\
\text { hari dalam bahasa } \\
\text { atau simbol } \\
\text { matematika } \\
\text { dengan jawaban } \\
\text { belum benar }\end{array}$ & $\begin{array}{l}\text { menyatakan } \\
\text { peristiwa sehari- } \\
\text { hari dalam } \\
\text { bahasa atau } \\
\text { simbol } \\
\text { matematika } \\
\text { dengan jawaban } \\
\text { sebagian benar }\end{array}$ & $\begin{array}{l}\text { menyatakan } \\
\text { peristiwa sehari- } \\
\text { hari dalam } \\
\text { bahasa atau } \\
\text { simbol } \\
\text { matematika } \\
\text { dengan jawaban } \\
\text { sebagian besar } \\
\text { benar }\end{array}$ & $\begin{array}{l}\text { menyatakan } \\
\text { peristiwa sehari } \\
\text { hari dalam } \\
\text { bahasa atau } \\
\text { simbol } \\
\text { matematika } \\
\text { dengan jawaban } \\
\text { benar }\end{array}$ \\
\hline $\begin{array}{l}\text { Membuat konjektur, } \\
\text { menyusun argumen, } \\
\text { merumuskan defenisi } \\
\text { dan generalisasi }\end{array}$ & $\begin{array}{l}\text { Membuat } \\
\text { konjektur, } \\
\text { menyusun } \\
\text { argumen, } \\
\text { merumuskan } \\
\text { defenisi dan } \\
\text { generalisasi } \\
\text { dengan jawaban } \\
\text { belum benar }\end{array}$ & $\begin{array}{l}\text { membuat } \\
\text { konjektur, } \\
\text { menyusun } \\
\text { argumen, } \\
\text { merumuskan } \\
\text { defenisi dan } \\
\text { generalisasi } \\
\text { dengan jawaban } \\
\text { sebagian benar }\end{array}$ & $\begin{array}{l}\text { membuat } \\
\text { konjektur, } \\
\text { menyusun } \\
\text { argumen, } \\
\text { merumuskan } \\
\text { defenisi dan } \\
\text { generalisasi } \\
\text { dengan jawaban } \\
\text { sebagian besar } \\
\text { benar }\end{array}$ & $\begin{array}{l}\text { membuat } \\
\text { konjektur, } \\
\text { menyusun } \\
\text { argumen, } \\
\text { merumuskan } \\
\text { defenisi dan } \\
\text { generalisasi } \\
\text { dengan jawaban } \\
\text { benar }\end{array}$ \\
\hline
\end{tabular}

Data hasil belajar diperoleh dari pemberian tes di akhir penelitian, dianalisis dengan menentukan jumlah peserta didik tuntas dan tidak tuntas dalam belajar, dan dibandingkan dengan Kriteria Ketuntasan Minimal (KKM) yang ditetapkan oleh sekolah yaitu 75. Hasil kemampuan komunikasi matematis dinilai mengacu pada rubrik skala kemampuan komunikasi matematis. Jika peserta didik memperoleh nilai sama atau melebihi 75 maka peserta didik tersebut dapat dikatakan telah tuntas dalam belajar. Sebaliknya jika kurang dari 75 maka peserta didik belum tuntas belajar. Pengembangan bahan ajar berbasis penemuan terbimbing ini dikatakan efektif jika lebih dari $65 \%$ peserta didik mendapat nilai lebih atau sama dari 75. 


\section{HASIL}

Hasil validasi terhadap soal tes terdapat saran untuk merevisi redaksi soal. Revisi yang dilakukan pada soal tes berdasarkan saran dari para validator dapat dilihat pada Tabel 2 .

\section{Tabel 2.}

Revisi Soal Tes Akhir

\begin{tabular}{|c|c|c|}
\hline Saran & Sebelum Revisi & Sesudah Revisi \\
\hline \multirow[t]{3}{*}{$\begin{array}{l}\text { Ubah } \\
\text { redaksi } \\
\text { soal }\end{array}$} & $\begin{array}{l}\text { Sebuah kapal berlayar dari } \\
\text { pelabuhan A kearah selatan menuju } \\
\text { pelabuhan B sejauh } 180 \text { km. } \\
\text { Kemudian dilanjutkan kearah timur } \\
\text { menuju pelabuhan C sejauh } 240 \\
\text { km. berapakah jarak terdekat } \\
\text { pelabuhan A ke pelabuhan C }\end{array}$ & $\begin{array}{l}\text { Sebuah kapal berlayar dari pelabuhan A kearah } \\
\text { selatan menuju pelabuhan B sejauh } 180 \mathrm{~km} \text {. } \\
\text { Kemudian dilanjutkan kearah timur menuju } \\
\text { pelabuhan C sejauh } 240 \mathrm{~km} \text {. Tentukan jarak terdekat } \\
\text { yang ditempuh kapal menuju pelabuhan C? }\end{array}$ \\
\hline & $\begin{array}{l}\text { Jelaskanlah apakah diantara tigaan } \\
\text { bilangan dibawah ini merupakan } \\
\text { tripel pythagoras! } \\
\text { a. } 5 ; 7 ; 8 \\
\text { b. } 9 ; 12 ; 15\end{array}$ & $\begin{array}{l}\text { Suatu ketika pak guru memberikan ucok dan buyung } \\
\text { masing-masing tiga bilangan. Ucok diberikan } \\
\text { bilangan } 5-7-8 \text {, sedangkan buyung diberi } \\
\text { bilangan } 9-12-15 \text {. Dari ketiga bilangan yang } \\
\text { diterima ucok dan buyung, mereka diminta } \\
\text { menentukan tripel pythagoras. Jelaskan menurut } \\
\text { kamu, apakah tiga bilangan yang diterima ucok dan } \\
\text { buyung tersebut merupakan tripel pythagoras? }\end{array}$ \\
\hline & $\begin{array}{l}\text { Dari tigaan bilangan berikut! } \\
\quad \text { a. } 7 ; 9 ; 11 \\
\text { b. } 8 ; 15 ; 17 \\
\text { c. } 4 ; 3 ; 6 \\
\text { Jelaskan jenis segitiga yang } \\
\text { terbentuk! }\end{array}$ & $\begin{array}{l}\text { Ibu membuat tiga jenis cokelat berbentuk segitiga } \\
\text { dengan masing-masing cokelat memiliki ukuran } \\
\text { yang berbeda-beda. cokelat pertama memiliki } \\
\text { ukuran sisi terpanjang } 6 \mathrm{~cm} \text { dan panjang sisi-sisi } \\
\text { lainnya } 4 \mathrm{~cm} \text { dan } 3 \mathrm{~cm} \text {. Cokelat kedua memiliki } \\
\text { ukuran sisi terpanjang } 11 \mathrm{~cm} \text { dan panjang sisi-sisi } \\
\text { lainnya } 9 \mathrm{~cm} \text { dan } 7 \mathrm{~cm} \text {. cokelat ketiga memiliki } \\
\text { ukuran sisi terpanjang } 17 \mathrm{~cm} \text { dan panjang sisi-sisi } \\
\text { lainnya } 15 \mathrm{~cm} \text { dan } 8 \mathrm{~cm} \text {. Dari ketiga cokelat yang di } \\
\text { buat ibu, jelaskan jenis-jenis segitiga yang terbentuk } \\
\text { dari masing-masing cokelat tersebut! }\end{array}$ \\
\hline
\end{tabular}

Berdasarkan hasil tes akhir peserta yang di ikuti sebanyak 34 orang menunjukkan bahwa nilai di atas KKM sebanyak 24 orang dengan persentase 70,5\% dan nilai di bawah KKM sebanyak 10 orang dengan persentase 29,5\%. Masih adanya peserta didik yang yang belum berhasil mencapai KKM, kemungkinan disebabkan saat proses pembelajaran berlangsung peserta didik tidak fokus saat diskusi dan tidak serius mengerjakan latihan, sehingga menyebabkan peserta didik tidak mampu menjawab soal tes dengan baik. Dari hasil tes akhir ini, diketahui lebih dari 65\% peserta didik berada di atas KKM. Dengan demikian disimpulkan bahwa kemampuan komunikasi matematis peserta didik setelah menggunakan bahan ajar matematika penemuan terbimbing meningkat. Ini menunjukkan bahwa bahan ajar matematika berbasis penemuan terbimbing sudah efektif untuk meningkatkan hasil belajar peserta didik. 


\section{KESIMPULAN}

Berdasarkan hasil penelitian, maka diperoleh kesimpulan bahwa bahan ajar matematika berbasis penemuan terbimbing yang dikembangkan sudah efektif dalam meningkatkan kemampuan komunikasi matematis yang dilihat dari hasil belajar peserta didik yang lebih dari 65\% mencapai KKM. Pengembangan bahan ajar ini mengacu pada prinsip pembelajaran yang memberikan kebebasan pada peserta didik untuk belajar dengan kemampuan dan kecepatannya sendiri. Pada pembelajaran menggunakan bahan ajar ini, dituntut kemandirian peserta didik dalam melakukan serangkaian aktivitas pembelajaran. Penggunaan waktu dalam pembelajaran dengan menggunakan bahan ajar tergantung pada kemampuan peserta didik dan cara guru mengkondidikan keadaan. Jika peserta didik berkemampuan tinggi kendala waktu tidak menjadi masalah, tetapi jika peserta didik di dalam kelas banyak memiliki kemampuan rendah, tentu penggunaan bahan ajar ini sedikit kurang efektif.

\section{DAFTAR PUSTAKA}

Akker,J.V. 1999. Principles and Methods of Development Research. In J. Vamden Akker, R Branch, K, N Nieveen and Tj. Plomp (Eds). Design Approaches and Tools in Education and Training (hlm. 1-14). Dodrecht: Kluwe Academic Publisher.

Depdiknas. 2014. Peraturan Menteri pendidikan Nasional Nomor 58 Tahun 2014 Tentang Kurikulum 2013 Sekolah Menengah Pertama/Madrasah Tsanawiyah. Jakarta: Badan Standar Nasional Pendidikan.

NCTM. 1989. Profesional Standards for Teaching Mathematic. Reston, VA: Author.

Plomp, Tjeerd. Educational Design Research: an Introduction. Dalam Tjeerd Plomp dan Nienken Nieeveen (Ed.). 2010. An Introduction to Educational Design Research. Enschede: SLO Netherlands Institute for Curriculum Development.

Sumarmo, Utari. 2003."Pembelajaran Keterampilan Membaca Matematika Pada Siswa Sekolah Menengah Dan Calon Guru”, (online). http://www.academia.edu/4609768/Sumarmo_Pembelajaran_Keterampilan_Membaca Mate matika pada Siswa Sekolah Menengah, diakses 01 Juli 2015.

Yazid, A. 2011. Kevalidan, Kepraktisan, dan Efek Potensial Suatu Bahan Ajar. Pascasajana Pendidikan Matematika Universitas Sriwijaya. http:/aisyahyazid.blogspot.com/2011/12/kevalidankepraktisan-dan-efek.html 